\title{
The Role of Symbol in Delivering the Theme of Reviving Power of Sex in Tennessee Williams' Orpheus Descending
}

\author{
Ahmadi Mosaabad Masoud (Corresponding author) \\ Assistant professor, English Department, Faculty of Arts, Gonbad Kavoos University \\ Gonbad Kavoos, Glostan province, Iran \\ Tel: 98-91-1376-1217Ｅ-mail: ahmadimousa@yahoo.com
}

\author{
Ahmad Gholi \\ lecturer, English Department, Faculty of Arts, Gonbad Kavoos University \\ Gonbad Kavoos, Golestan province, Iran
}

Tel: 98-91-1771-5701_E-mail: freehero3000@yahoo.com

Received: May 9, 2011

doi:10.5539/ells.v1n2p123
Accepted: May 26, 2011

Published: December 1, 2011

URL: http://dx.doi.org/10.5539/ells.v1n2p123

\begin{abstract}
Dating back to the second half of Stone Age, Symbol is the mother of art and culture. Being omnipresent, symbols are interwoven to the humans' life, thereby becoming their inseparable aspect of living. In the realm of literature, they are categorized into two types: public and private. The symbolic import of public symbols is determined by a particular culture while that of private ones is determined by the writer himself/herself. Symbols play different roles in a literary work; one of them is delivering its theme(s). In American literature, Tennessee Williams is well-known for utilizing symbols widely in his plays. In fact, he expressed his world views through the language of symbols. Therefore, this article makes an endeavor to show how guitar as a private symbol pushes forward the theme of life-giving force of sex in Williams's Orpheus Descending.
\end{abstract}

Keywords: Symbol, Theme, Guitar, Life-giving force, Sex

\section{Introduction}

The current study starts with a look at the brief history of symbol and sex in literature. Then the plot summary of The Orpheus Descending will be presented in order to complement the main discussion of the article: the role of the guitar as a private symbol in delivering the theme of the reviving power of sex in the play. In the final step the relationship between the symbol in question and aforementioned theme will be closely scrutinized.

\subsection{Symbol}

"Dating back to the second half of Stone Age" (Cirlot, 2001, p. 10), symbol simply "stands for an object, place, or incident representing some abstract idea or situation" (Quinn, 2006, p. 408). Generally, in literature, there are two broad types of symbols: conventional and private. The symbols which "[their symbolic] significance are determinate within a particular culture" (Abrams, 2005, p. 320) are called conventional symbols while the symbols which their symbolic meaning is generated by the author are named private symbols. The quality which differentiates the private symbols from the public ones is the vitality and originality of the private symbols; that is to say, unlike hackneyed public symbols, they originate from the fertile imagination and invaluable and personal experience of the author. Symbol can perform various roles in a literary work such as conveying the writer's outlook indirectly, connecting the world of reality with the inaccessible domain of abstract world, and mystifying the work which in turn adds more beauty to it. So pivotal, practical, and mysterious concept, the symbol has captured the meticulous and careful attention of well-known philosophers like Plato and Coleridge.

Plato through his 'cave parable' in Republic presents his view about symbol,

picture men dwelling in a sort of subterranean cavern with a long entrance open to the light on its entire width. Conceive them as having their legs and necks fettered from childhood, so that they remain in the same spot, able to look forward only, and prevented by the fetters from turning their heads. Picture furthers the light from a fire burning higher-up and at a distance behind them, and between the 
fire and the prisoners (Habib, 2005, p. 22).

Plato believes that human beings (cave dwellers) due to their limitation and being earth-bound (fetters) cannot get access to the world of Idea but they can experience it through (Pictures) shadows in the wall of the cave. In other words, human beings can realize Truth by means of symbols. Similarly Habib (2005) notes "Plato's point is that people who have known only these shadows will take them for realities" (p.22). Thus symbols for Plato function like a mediator between the world of Form and the earth.

Coleridge regards symbol as the product of imagination and a bridge between the concrete and private world with abstract and general world and superior to allegory,

"Coleridge regards the symbol as a product of the human imagination that bears witness to the presence of the Eternal ... in the most humble images of everyday life. He stresses the tangible quality of symbolic language, its ineluctable grounding in the temporal world. Allegory, on the other hand, is inferior to symbol" (Mckusick, 2006, p. 223).

Symbol attained considerable importance and prestige in the second half of nineteenth century among the new generation of French Poets such as Charles Baudelaire, Stephen Mallarme, Paul Verlaine, and Arthur Rimbaud who were tired of realism and naturalism. These poets set up symbolism as a literary movement and introduced it to the world. Later on, at the turn of the century, this movement was flourished in drama by Maurice Maeterlinck. In American drama, Tennessee Williams is well-known for using symbols widely in his plays. To illustrate the point, we can refer to what Williams (1987) states "symbols are nothing but the natural speech of drama ... the purest language of plays" (p. 66). He adds that "art is made out of symbols in [the same] way your body is made out of vital tissue" (p. 45). These quotations beautifully illustrate how symbols are important for him not only to convey his inmost feelings and view points in his plays but also to push forward the themes in his plays. This study makes efforts to show how guitar as a symbol in the play moves forward the theme of life-giving power of sex.

\section{$1.2 \mathrm{Sex}$}

The enigmatic nature of sex and the powerful force, which it can exert on human beings, have obsessed the minds of artists and poets from the early times. Therefore, it is not surprising to find that "sex was a powerful strategy for Sumerians to civilize Enkidu, Gilgamesh's counterpart" (Abramson \& Pinkerton, 1995) or the sketches of sexually appealing royal women on the walls of the sacred chambers of pyramids in ancient Egypt, or Sophocles' tragedy, Oedipus Rex, which properly deals with the issue of sex. There were different attitudes towards sexuality in the Middle Ages, Renaissance, the Victorian Period, and the $20^{\text {th }}$ century. In Middle Ages, when Popes were dominant in the society, sexuality was considered as either an appropriate means to reach God or a powerful temptation capable of deviating the subjects from the right path of virtue, modesty, and salvation; as a result, they encouraged celibacy and virginity instead of making sex. Moreover, "they allowed sexuality for the sole aim of procreating" (Grendler, 2004). But in the Renaissance, a shift took place in the attitudes of church towards sexuality: it permitted the married to enjoy sexual pleasure which is not for the aim of producing children. In the Victorian period, when the bourgeoisie played key role in making law, sex and its power was regarded very dangerous, thus they "opposed, silenced and eliminated sexuality as far as possible" (Gutting, 2005, p. 109). It explains why they meticulously censored and banned literary works dealing frankly with sexual issues. In this period in addition 'sexology' as a new area for research was emerged in Germany, France, and Austria. It focused on those people who were 'sexually' sick (Downing, 2008). Unlike three above mentioned times in which talking and writing about sex and sexual issues in public and press were very shocking and immoral, in the twentieth century, with groundbreaking work of Sigmund Freud the attitudes towards sex completely changed. He speculated that art and literature are sublimated form of sexual desires. His speculation about sex was a complete revolution in the history of sex. Consequently, from that time the issue of sex attained a unique place in literary criticism, literature, art, psychology, psychoanalysis, and sociology, to name some. This explains why the existence of many books, magazines, movies, and TV shows dealing with the issue of sex from different perspectives. Moreover, in the second half of $20^{\text {th }}$ century, French Scholar and critic Michel Foucault closely examined the issue of sexuality and the science of sexuality in modern time. He concludes that sexuality and sexology at the hand of bourgeoisie is a tool for gaining enough knowledge in this area in order to maintain their power and control over people (Gutting, 2005). Interestingly, one of the themes which repeatedly appear in Tennessee Williams' plays is the life giving power of sex. Debusscher notes that D. H. Lawrence had great impact on Williams because of,

Englishman's emphasis on sexuality: to him sex was a means of restoring a balance between the two antagonistic forces of the flesh and the spirit, locked in a battle in which the British writer felt the intellect had dangerously gained the upper hand. Sex was also a liberating force opposed to the bourgeois Puritanism of Victorian Age and of the American Genteel Tradition (2001, pp. 168-169).

The reviving and liberating aspect of sex which appears in Lawrence's works in particular his Lady Chatterley's Lover 
absorbs Williams's attention. Lawrence in Lady Chatterley's Lover beautifully illustrates the healing power of sex. The novel tells the story of Connie, a sexually frustrated wife of successful writer and businessman. Having mercenary attitudes towards his writing, her paralyzed and sexually impotent husband not only ignores Connie's sexual needs but also he wholeheartedly devotes his time and energy to his writing profession. The fact that he fails to meet her sexual urges causes deep and impassable gulf between the couple. Into Connie's miserable life enters Oliver Mellor who works as a servant in her husband's farm. In her several meeting with him, she makes love with him. His amazing sexual energy gives life and saves her from falling into the vortex of disappointment and severe seclusion. Moller with his reviving sexual energy serves as a good model for Williams' virile characters like Val Xavier in Orpheus Descending. Since the theme of life-giving power of sex is prominent, this study makes effort to explore how guitar symbolism assists the playwright to develop the theme in question.

\section{Plot Summary}

The Orpheus Descending tells the story of a handsome guitarist, Val who comes to Two River County where he gets familiar with two sexually undernourished and oppressed women: Vee Talbot and Lady Torrence, the latter being the daughter of an Italian immigrant whose wine-garden was burnt by Jabe and his mob due to her father's selling of wine to some black people. After the bitter event, David, Lady's boyfriend, jilts her in order to marry a rich girl. Having no choice and unaware of Jabe's role in her father's death and the destruction of his wine-garden, she unwillingly marries him to ensure her financial security. Unemployed and looking for a job, Val asks Lady Torrence to employ him in her store. Under the influence of his impressive speech about his guitar, his some strange skills, and the legless bird, Lady accedes to take him into employment and give him a place to sleep in the store. The presence of Val enlivens the dead and barren life of Lady and Vee. He makes Lady pregnant and become the reason for her optimism, and inspires visionary Vee to paint ascending Jesus Christ. When Sherriff sees Val touching Vee, and she is kissing him, he gives him an ultimatum: either leave the town or accept the death at the hands of his angry group. Under Sheriff's duress, Val makes the decision of going away of the town; his decision disturbs Lady. Val insists that he has to live, but Lady implores him to stay till her sick husband dies so that they leave the place together. Jabe's nurse who sees them informs Jabe of their secret relationship and intention. Gaunt and sick Jabe comes out angrily and shoots, and wounds Lady. Then he cries and claims that Val fired his wife. Hearing his cry, some men come and one of them burns Val with his blowtorch.

\section{Discussion}

In his book, Literature: Structure, Sound, and Sense, Perrine believes that "it is the whole context of a literary work which determines and controls the possible meaning of a personal symbol...[and] one way to detect a symbol is its repetition in the work" (qtd. in Kesauly and Hermansyah, 2004, p.63). According to Kenney "in order to look for symbols it is necessary to focus on certain characters and actions because usually the author invents them based on certain purposes, by holding up for inspection certain characters and their actions, the author lends them some special significance in order to support the idea [theme]" (qtd. in Kesauly and Hermansyah, p. 64). When one directs his full attention to the entire context of the play, one will find that the word (image) 'guitar' not only is repeated for 64 times in the course of the play but also he will realize that it is related to the main characters, action, and mythic understructure of the play. Therefore it is safe to consider the guitar as a personal symbol in the play. In addition, since the guitar is interconnected with other parts of the play, it is not illogical to claim that it gives thematic weight to the play. In the play in scrutiny, there are some events in the lives of Lady and Sherriff as well as the mythic structure of the play which prove that guitar symbolizes Val's sexual power, and as an important symbol pushes forward the theme of life- giving energy of sex.

Lady Torrance, Jabe's wife, is leading a hopeless and miserable life because she was jilted by David, her former boyfriend, after her father's death. His marriage to a society girl broke her heart, leaving her no option but marrying Jabe against her own wishes to guarantee her financial security in materialistic society. Since her husband suffers from cancer, he is too weak to meet her sexual needs; it explains why "her face is taut. She is a woman who met with emotional disaster...verges on hysteria under strain" (Williams, 1968, p. 146). Her ruined sex life became evident through Dolly's comment on their bedroom and Jabe's cold store which Lady runs it. Through her conversation with Beulah in front of the store, Dolly provides the readers with inviolable information about Jabe and Lady's bedroom and their separate beds, "they got two separate bedrooms which are not even connecting. At the opposite ends of the hall, and everything is so dingy an' dark up there. Y'know what it seemed like to me? A country jail!" (p. 131). Her description of their isolated beds superbly illustrates two points. Firstly, it accurately reflects the great physical and emotional distance between them which renders them like two separate islands in the ocean of marital life. Secondly, it clearly indicates that Lady does not derive proper sexual pleasure, which is capable of sweeping away enmity and cementing the injured relationship. Jabe's lack of sexual vitality and genuine emotional warmth makes her life wretched and dark because for Lady a life without a glow of sexual pleasure is not different 
from rusting away in the prison of lonely life. Another thing which effectively demonstrate Lady's sexually miserable life is Jabe's cold store which Lady runs it, "Christ...I'm shivering!-it's cold as a goddam ice-plant in this store, I don't know why, it never seems to hold heat...it don't hold heat at all” (p. 155). The fact that Lady feels cold and shivers in the store supports the claim that her life lacks human warmth for which Lady desperately craves in her life. In fact she is in the winter of her life. But the presence of unemployed Val with his guitar and warm body for Lady is the harbinger of the spring, love, and sexual satisfaction. When Val wants Lady to employ him in the store, his warm body attracts her attention,

VAL: It's warm from my body, I guess...

LADY: You must be a warm--blooded boy...

VAL. That's right...

VAL: That happens $t^{\prime}$ be the truth. My temperature's always a couple degrees above normal the same as a dog's, it's normal for me the same as it is for a dog, that's the truth... ( $p .155)$.

Their short conversation is highly important due to containing two weighty words: 'warm blooded' and 'dog.' In his book, Dictionary of Symbols, Cirlot (2001) associates the state of being warm blooded with fire, and fire with animal passions. He also notes that dog in literature symbolizes masculinity and courage. From his speech, Lady seems to infer that masculinity and powerful sexual energy is his trade mark and sharply distinguishes him from his husband and it explains why she is fascinated and attracted by him. Williams masterfully in the course of the play symbolizes powerful sexual power of the guitar. In the life of Lady two significant events take place which brilliantly illustrate two main points: first, Val's guitar symbolizes his sexual power (or phallus); second, the guitar as the private and crucial symbol advances the theme of the life-giving power of sex. The first major event happens when Lady unjustly accuses Val for exhibiting suggestive sexual behaviors and making sexual advance on a female customer in the store. Since Val regards her accusation unsubstantiated, he picks up his guitar in order to leave the store forever. To prevent Val from leaving the store, Lady firmly grasps his guitar because she full well knows that if he departs from the store, she will be desperately alone, sexually unfulfilled, and psychologically unstable, thus she says to him, "I told you I'm sorry. You want me to get down and lick the dust off your shoes?" she continues, "I ain't dissatisfied with you. I'm pleased with you, sincerely!" (Williams, p. 166). In her speech, there are words: 'ain't dissatisfied' and 'pleased' which reflects Lady's strong feeling on Val's sexual appeal. The words in question put emphasis on the fact that she needs Val's sexual stamina and warm body to gratify her sexual urges which have been ignored by her impotent husband. In addition, the notion that she clutches his guitar firmly and is unwilling to hand it to him confirms the point that she is in the desperate need of the powerful sexual energy which Val offers properly. Moreover, Val claims that his guitar, his life companion, is capable of purifying something unclean, "it washes me clean like water when something unclean touched me" (p. 157). Lady grasps his guitar tightly because she knows very well that Val's sexual love and energy like water not only washes the bad memories of her father and former unfaithful boyfriend, but also compensates her sexual undernourishment caused by Jabe. In other words, Val's amazing and restoring sex which is symbolized by his guitar regenerates her and makes her to forget her present plight and predicament. Furthermore, Val deeply believes that human beings know each other by their close contact and sexual intimacy; and his belief markedly influences Lady; therefore, she fears that Val's untimely departure will deprive her of sexual warmth and intimacy, and aggravate her already dark and sexually impoverished life, it explains why she grips hard his guitar, which is the symbol of his dynamic and revitalizing sex. In short, Lady's firm grasp of Val's guitar indicates two main points. One is that his guitar stands for his sexual energy and the other, the guitar as a quintessential symbol in the play pushes forward the theme of the life-giving power of sex.

The second major event proves that Val's guitar not only symbolizes his vivifying sexual power but also moves ahead the theme of vitalizing power of sex. It occurs in the final scene in which Sheriff who thinks that Val is seducing his innocent wife, threatens Val with agonizing death if he stays in the town. Under Sheriff's death threat, Val prepares to leave the city much to Lady's chagrin and surprise. Trying to deter him from going away, she says that if he leaves the store, she will not pay his wages, but in vain. When Lady fails to persuade him to stay, she grabs his guitar firmly and says to him, "longer, and longer than morning! I am going to keep hold of your "life companion' [guitar] while I pack! I'm goin' to pack an' go, if you go, where you go!” (p. 217). Lady wants to accompany Val wherever he goes because she feels that her life without Val and his sexual power is void, and she will rot in the jail- like store, "You didn't think so, you actually didn't think so? What was I going to do, in your opinion? What, in your opinion, would I be doing? Stay on here in a store full of bottles and boxes while you go far, while you go fast and far, without me having your--forwarding address!--even?" (ibid.).The notion that Lady is unwilling to let Val leave her store, grabs his guitar firmly, and wants to departs the city with him beautifully illustrates that Val's sexuality is the center of Lady's' life and without his life-giving sexuality, she will be like a 
lunatic woman and uninterested in life. Another reason for her firm grip on his guitar is that Lady also who has been infertile and hopeless for many years, perfectly knows that it was Val's sexual potency which impregnated her, and in turn changed her life dramatically,
When a woman's been childless, as long as I've been childless, it's hard to believe that you're still able to bear! ... We used to have a little fig tree between the house and the orchard. It never bore any fruit, they said it was barren. Time went by it, spring after useless spring, and it almost started to---die... Then one day I discovered a small green fig on the tree they said wouldn't bear! ... I ran through the orchard. I ran through the wine garden shouting, 'Oh, Father, its going to bear, the fig tree is going to bear!'--It seemed such a wonderful thing, after those ten barren springs, for the little fig tree to bear, it called for a celebration...I've won, I've won, Mr. Death, I'm going to bear! (p. 221).

Before Val's arrival with his guitar to Two River County, Lady was barren and hopeless like the infertile fig tree in her father's garden, but then Val with his warm body and powerful sexual energy enters into her cold and passionless life. From then on, she feels that the harsh winter of her life is ending and the new era in her life is dawning because he makes her pregnant, thereby helping her to bloom and come into flower like the barren fig tree which produced green fig after many years of being fruitless, "I have life in my body, this dead tree, my body, has burst in flower, you've given me life" (ibid). From what is said it can be concluded that the fact that Lady firmly grasps Val's guitar and wants to accompany her wherever he wants, substantiates the point that Val's guitar embodies his vivifying sexuality and it as an essential symbol in the play pushes forward the theme of life-giving power of sex.

The overall context of the play makes it clear that Sheriff also sexually has oppressed Vee, his wife; she is attracted to the sexual magnetism of Val which explains why she paints ascending Jesus in the shape of Val. In the final act, one main event happens to Sheriff which gives credibility to the idea that Val's guitar is both the symbol of his sexual vitality and deliverer of the theme of life giving power of sex. This event occurs when Vee with excitement comes to the store in order to share with Val her vision in which Jesus is ascending to the Heaven. To do so, she throws her arms around Val and accounts her vision to him. When Val wants to lift her arms, Sheriff comes to the store and sees the scene; he thinks that Val is seducing his plain wife, thus he forces Val to leave her, "let go of her, do not put your hands on my wife!" (Williams, p. 204) and threatens Val with death if he does not leave the place with his guitar till the morning, "but if you value that instrument in your hands as much as you seem to, you will simplify my job by not allowing the sun tomorrow to rise on you in this county, ' understood, now, boy?" (p. 207). The fact that Sheriff places more emphasis on Val's guitar makes this point clear that Sheriff is acutely aware that the secret behind Val's magnetism is his irresistible sexual power; as a result, he hates his guitar and believes that it is the root cause of his wife's seduction. Consequently, he lays stress on his leaving the town with his guitar. Moreover, Sheriff knows very well that he has sexually frustrated his wife, thus he feels stab of jealousy. In similar vein, Galens notes that "Sheriff feels sexual jealousy of Val's virility, that is why his guitar fascinates her" (2003, p. 165), "let me see your guitar" (Williams, p.205) and wants more details about it "what is all writing on the guitar" (p. 206). Sheriff and his friends threaten him with knife in this scene; their violent acts, according to Galens, indicate that "they want to castrate Val whom they consider a rival"(2003, p. 166), "son of low-down bitch foolin' with that ought to right [Vee] to be cut [castrated] the son of [bitch]" (Williams, p. 204). To put in nutshell, the fact that Sheriff forces Val to leave the town with his guitar and associates it with his sexual vitality and the main cause of his wife's seduction, clearly indicates that Val's guitar represents his sexual power and as a very important symbol in the play it moves ahead the theme of the life-giving power of sex.

The legend of Orpheus and Eurydice on which The Orpheus Descending is based clearly demonstrates that Val's guitar stands for his sexual energy and advances the theme of the life-giving power of sex because in the legend Orpheus's lyre functions like Val's redemptive sexuality (guitar). The myth tells the story of Orpheus whose beloved, Eurydice, dies when a snake hidden in the grass bites her. Crestfallen and sad, he decides to bring her sweetheart back from Underworld, the destination of dead people. Knowing that entering Hades is a Herculean task, he relies on his electrifying musical performance to deliver her from there. So he plays his lyre so sweetly that he easily persuades deities and guardians of Hades to permit him enter there and take his beloved, Eurydice, to the earth once more but on one condition: he should not look back to see his beloved till he ends his journey. But near to the gate of Hades, he turns his head to see whether Eurydice feels tired or not; as a result, his beloved disappears at that moment. Like Orpheus, Val comes to Two River County (Hades) to rescue Lady (Eurydice) of her unsatisfactory and soulless life, which her husband designed for her. Just as Orpheus who was temporally successful in bringing Eurydice from Hades by means of his electrifying music, Val emerged triumphant for a short time with awakening Lady's sexual desire and giving life through his sexual power which is symbolized by his guitar. So Val's guitar has two layers of meanings. On the surface level it is a musical instrument for playing songs like 'Heavenly Grass.' But, in deep level it symbolizes Val's revitalizing sexual energy through which he impregnates Lady. Accordingly, 
Williams with incorporating the legend of Orpheus accentuates Val's invigorating sexual energy through the symbol of the guitar. Doing so, the playwright advances the energizing power of sex.

\section{Conclusion}

To summarize, one of the distinguishing features of Tennessee Williams's plays in particular The Orpheus Descending is his wide utilization of symbols. He does not employ them just for the sake of ornamentation but he uses them for building bridge between form and content. For instance, in The Orpheus Descending, he takes advantage of guitar as a potent symbol for delivering the theme of the life-giving power of sex. some events in the lives of Lady and Sheriff along with mythic structure of play brilliantly illustrate the point that Val's guitar is the symbol of his phenomenal sexual power and as a main symbol in the play it delivers the life-giving power of sex. Val with his amazing sexual power which is symbolized by his guitar gives life to Lady whose sexual urges suppressed by her husband. Val enriches Lady's sad and barren life with his vivifying sexual stamina. Before Val, Lady's life was void and soulless because of her unhappy marriage with Jabe who burnt her father's vine orchid, caused his death and led to her lover's abandonment. But Val with his vitalizing sexuality liberated her from talons of despair, and made her barren life fruitful with impregnating her, that is why when he wants to leave the store and city, she tightly grasps his guitar, symbol of his phallus, and genuinely implores him to stay beside her because she is well aware of this fact that her life will be void and miserable without him. Another event which mirrors the key role of the guitar symbolism and its relation with theme, takes place when Sheriff sees his wife, Vee, embraces Val to share her vision in which she saw ascending Jesus. Witnessing the scene, Sheriff thinks that Val is seducing his simple wife; as a result, he threatens Val with death if he does not leave the city till morning with his guitar. That Sheriff's emphasis on Val's leaving the city with his valuable instrument, guitar, reveals his own impotency and Val's powerful sexual attraction. Finally, the legend of Orpheus and Eurydice brightly reflects that Val's guitar embodies his amazing sexual energy and as a symbol which interconnected with other parts of the play it pushes forward the theme of life-giving power of sex. Just as Orpheus in the myth of Orpheus and Eurydice who for a short time brings out his beloved from the Hades with his lyre, Val through his sexual magnetism which is symbolized by his guitar temporarily saves Lady and Vee from the dark and cruel world their husbands created for them.

\section{References}

Abrams, M. H. (2005). A Glossary of Literary Terms. Boston: Thomson Wadsworth.

Abramson, Steven, \& Pinkerton, Paul. (1995). With Pleasure: Thoughts on the Nature of Human Sexuality. New York and Oxford: Oxford University Press.

Cirlot, J. E. (2001). "Dog" and "Fire". A Dictinary of Symbols. Jack Sage (Trans.). London: Routledge.

Debusscher, Gilbert. (2001). European and American Influences on Williams. Matthew. C. Roundre. (Ed.). Cambridge: Cambridge University Press.

Downing, Lisa. (2008). The Cambridge Introduction to Michel Foucault. Cambridge: Cambridge University Press. http://dx.doi.org/10.1017/CBO9780511793240

Galens, David. (Ed.). (2003). Drama for students, 17. Farmington Hills, MI: Gale Group.

Grendler, Paul. (Ed.). (2004). Renaissance: an Encyclopedia for Students. Atitudes toward Sex, Vol. 4. N.J.: Princeton.

Gutting, Gary. (2005). Foucault: Very Short Introduction. New York and Oxford: Oxford University Press.

Habib, M. A. R. (2005). Modern Literary Criticism. Oxford: Blackwell Publishing. http://dx.doi.org/10.1002/9780470752142

Kesauly, Rosemary \& Hermansyah, S Harris, (2004). Symbols as a Means of Delivering the Theme in Nabokov's Lolita. [Online] Available: http://www.Chomikuj.pl.com (January 10, 2011).

Mckusick, James. (2002). "Symbol" Newlyn, Lucy. The Cambridge Compainon to Coleridge. Cambridge: Cambridge University Press. http://dx.doi.org/10.1017/CCOL0521650712.015

Quinn, Edward. (2006). A Dictionary of Literary and Thematic Terms. New York: Facts on File.

Williams, Tennessee. (1968). Orpheus Descending. London: Penguin Books.

Williams, Tennessee. (1987). Where I Live. New York: New Direction. 